\title{
Rocky Mountain spotted fever in a pediatric hospital in northeastern Mexico
}

\author{
Miguel Á. Martínez-Medina* \\ Departamento de Enseñanza e Investigación, Hospital Infantil del Estado de Sonora, Hermosillo, Sonora, Mexico
}

I have read with great interest the work on the treatment experience of Rocky Mountain spotted fever (RMSF) in a pediatric hospital in Saltillo, Coahuila ${ }^{1}$, which reports relevant facts that allow me to comment on some aspects of the disease in our environment. The reported overview is similar to the experience we have had in the state of Sonora. This disease, denied during 2003, has become a cruel reality due to its high lethality. Examining the cases and understanding the sociodemographic conditioners have made it possible to identify the factors that explain, at least in part, the severe cases and deaths due to this condition.

The findings of Bustamante and Ortiz Mariote in the 1940 s that confirmed the existence of American spotted fever and the identification of the brown dog tick, Rhipicephalus sanguineus, as well as an outbreak in Alamos during 1948 with an $80 \%$ lethality, are the historical antecedents of the reemergence of this condition in Sonora from the first decade of the $21^{\text {st }}$ century. ${ }^{2}$

Undoubtedly, the diagnosis of RMSF by Rickettsia rickettsii is a challenge, and the management of its most severe forms is a significant medical challenge. In particular, I consider that the RMSF treatment has been approached almost exclusively as a bacterial infection subject to the administration of an antibiotic (doxycycline). However, physiological alterations regarding body fluids and volumes have been disregarded, among which the increase in extracellular and interstitial water, the excessive secretion of antidiuretic hormone, and a greater plasma volume stand out.
Therefore, its high lethality has been attributed to both the rickettsia virulence and the delay of treatment. Even enzymatic deficiencies have been considered in tients who do not survive.

In contrast, a recent case study reports high morfality in cases diagnosed at an early stage that had also-received adequate treatment with doxycycline. ${ }^{3}$

Experience has shown that after resuscitation with crystalloid boluses, patients in shock due to rickettsiosis frequently progress with signs of hypervolemia at respiratory, cardiac, or brain level, and more than $60 \%$ die within the first 72 hours of hospitalization. In this regard, a study conducted in children with this disease confirmed that the administration of fluid loads is significantly associated with neurological sequelae or death. ${ }^{4}$ Moreover, Maitland et al., in 2011, reported that resuscitation with saline or albumin boluses is associated with a significant mortality increase in a group of African children with severe infectious disorders, compared with another group of children who only received maintenance fluids $(2.5-4 \mathrm{ml} / \mathrm{kg} / \mathrm{h}) .^{5}$

Despite these findings, the most recent updates of the Surviving Sepsis Campaign and the PALS (Pediatric Acute Life Support) guideline have not modified the regime for the resuscitation of patients consisting in solution boluses at a rate of 20 a $60 \mathrm{ml} / \mathrm{kg}$ during the first 15 min of care. ${ }^{6}$ However, in their report on the management of the critically ill child, 2016, a group of experts of the World Health Organization (WHO) introduced significant changes for the treatment of shock
Date of reception: 23-12-2018

Date of acceptance: 07-01-2019

DOI: 10.24875/BMHIME.M19000060
Available online: $14-01-2020$ Bol Med Hosp Infant Mex. 2019;76:97-98 www.bmhim.com 
with signs of severe hypoperfusion (capillary refill time $>3 \mathrm{~s}$, distal hypothermia, and weak or absent pulse) ${ }^{7}$ and not only the presence of arterial hypotension. WHO recommends the administration of crystalloids in boluses of $10-20 \mathrm{ml} / \mathrm{kg}$ for 30 to $60 \mathrm{~min}$, as well as case reassessment and, if necessary, another load of solutions at a rate of $10 \mathrm{ml} / \mathrm{kg}$ in $30 \mathrm{~min}^{7}$

In the current literature, there is a renewed interest in establishing the efficacy and safety of protocols with restrictive fluid management of children in shock. Although the results may be reflected only in the future, the findings of Maitland et al. ${ }^{5}$ and the WHO recommendations should be considered by performing an appropriate estimation of the severity of each case, careful handling of the resuscitation fluids and constant patient monitoring to decrease, as far as possible, the harmful effects of fluid overload.

\section{References}

1. López-Castillo DC, Vaquera-Aparicio D, González-Soto $M A$ Martínez-Ramírez R, Rodríguez-Muñoz L, Solórzano-Santos F. Fiebre manchada de montañas rocosas: experiencia en 5 años de vigilancia activa en un hospital pediátrico de segundo nivel en el noreste der México. Bol Med Hosp Infant Mex. 2018;75:303-8.

2. Martínez-Medina MA. Antecedentes históricos de la fiebre manchàda de las Montañas Rocosas en Sonora. Bol Clin Hosp Infant Edo Son 2009; 26:78-82.

3. Delgado-De la Mora J, Licona-Enríquez JD, Leyva-Gastélum M, Delgado-De la Mora D, Rascón-Alcántar A, Álvarez-Hernández G. A fatal case series of Rocky Mountain spotted fever in Sonora, México. Biomédica. 2018;38:69-76.

4. Buckingham SC, Marshall GS, Schutze GE, Woods CR, Jackson MA, Patterson LE, et al. Clinical and laboratory features, hospital course, and outcome of Rocky Mountain spotted fever in children. J Pediatr. 2007 ; 150:180-4.

5. Maitland K, Kiguli S, Opoka R, Engoru CH, Olupot OP, Akech S, et al. Mortality after fluid bolus in African children with severe infection. $\bar{N}$ Engl J Med. 2011;364:2483-95.

6. Gelbart B. Fluid bolus therapy in pediatric sepsis: current knowledge and future direction. Front Pediatr. 2018;6:308-15.

7. World Health Organization [Internet]. Updated guideline: pediatric emergency triage, assessment, and treatment: care of critically-ill children; 2018. Available from: https://www.who.int/maternal_child_adolescent/ documents/paediatric-emergency-triage-update/en 